Trinity College

Trinity College Digital Repository

Faculty Scholarship

$9-2014$

University of Radicalism: Ricardo Flores Magón and Leavenworth Penitentiary

Christina Heatherton

Trinity College, christina.heatherton@trincoll.edu

Follow this and additional works at: https://digitalrepository.trincoll.edu/facpub

Part of the History Commons 


\section{PROJECT MUSE}

\section{University of Radicalism: Ricardo Flores Magón and Leavenworth Penitentiary}

Christina Heatherton

American Quarterly, Volume 66, Number 3, September 2014, pp. 557-581 (Article)

Published by The Johns Hopkins University Press DOI: 10.1353/aq.2014.0044

$\Rightarrow$ For additional information about this article http://muse.jhu.edu/journals/aq/summary/v066/66.3.heatherton.html 


\title{
University of Radicalism: Ricardo Flores Magón and Leavenworth Penitentiary
}

\author{
Christina Heatherton
}

A fter decades of publishing, organizing, and agitating, the Mexican revolutionary and anti-imperialist visionary Ricardo Flores Magón was captured in what would be his final arrest in March 1918. A leader of the anarcho-syndicalist organization the Partido Liberal Mexicano (PLM), the major opposition group in Mexico, Flores Magón's calls for tierra y libertad (land and freedom) had articulated the radical aims of the Mexican Revolution. Through his paper Regeneración, he made clear that the struggle for freedom was global, extending throughout Mexico and beyond. As Emma Pèrez notes, "The discourse of the revolution knew no boundaries." Fittingly, it was not in his beloved Mexico where he was finally apprehended but among his comrades across the US-Mexico border in Los Angeles, California. ${ }^{1}$

Flores Magón and his coconspirators had been closely surveilled by governments on both sides of the border and throughout the borderlands, especially as they continued organizing and agitating. What prompted this final arrest by US authorities was not a directive to Mexican revolutionaries nor was it an attempt to solely organize Mexicans in Los Angeles; rather, it was an appeal to people around the world. In the midst of World War I, Flores Magón and his comrade Librado Rivera published "Manifesto to the Anarchists of the Entire World and to the Workers in General.” It proclaimed:

The death of the old society is close, it won't be long in coming. . . The citizen, who only yesterday considered the policeman his protector and supporter, now looks upon him with a grim gaze. . . the workingman goes on strike, aware that it is no longer important that his action injures the country's interests, since the country is no longer his property but the property of the rich. ${ }^{2}$

The anarchist manifesto characterized a generalized disillusionment felt by workers towards the states that purported to represent them. It further implied that a latent insubordination smoldered in the hearts of people worldwide. For this suggestion, Flores Magón and his coauthor were deemed a threat to US national security and charged with violating the Espionage Act, a new 


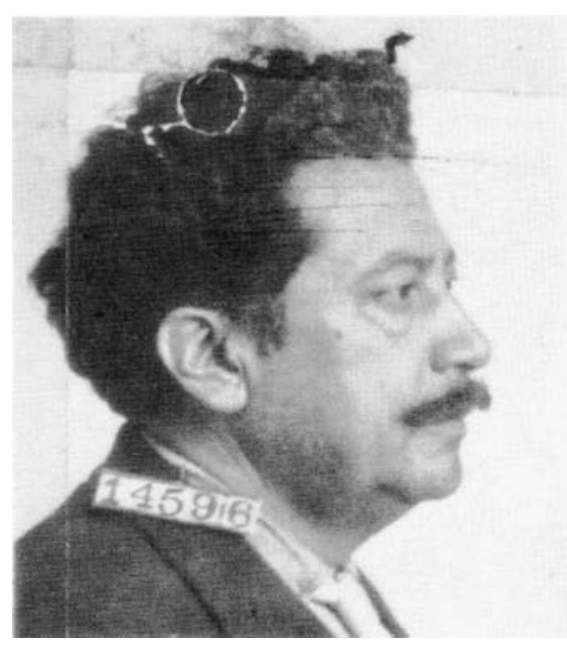

Figure 1

Ricardo Flores Magòn National Archives at Kansas City; Record Group 129, Records of the Bureau of Prisons; Department of Justice. Bureau of Prisons. U.S. Penitentiary, Leavenworth; Inmate Case Files, 1895- 1952; National Archives Identifier: 571125; Inmate 14596 Flores Magòn, Ricardo.

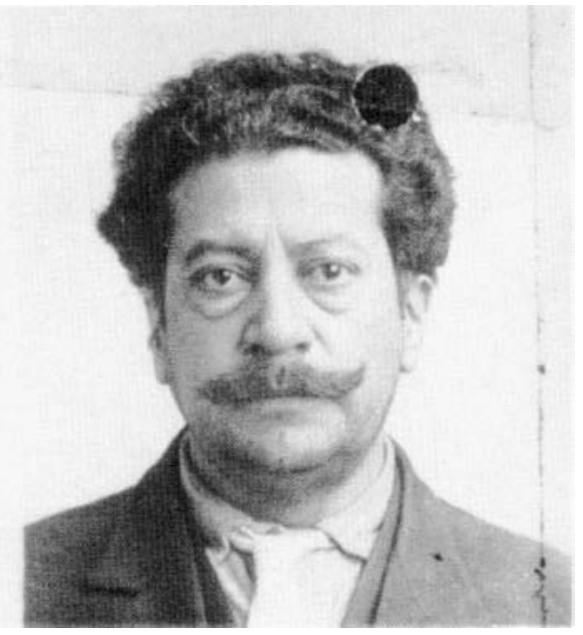

piece of federal legislation that deemed it a felony to make "false statements" which might cause insubordination or disloyalty in the military. This arrest would be Flores Magón's final after decades of surveillance, imprisonment, torture, and state repression in both the US and Mexico. For this crime, Flores Magón would die, or as many have argued, be killed, in Leavenworth Federal Penitentiary in Kansas. ${ }^{3}$

The ongoing repression of Flores Magón and his comrades was directly proportional to the popularity of their message among the poor and the working class around the globe. In his speeches and writings, Flores Magón had commanded the world to witness, support, and join the struggle for freedom, especially the struggle of the Mexican Revolution, which he saw as a battle against US imperialism, racism, and capitalism. While a frail, older, and quite sickly man at the time of his arrest, Flores Magón was deemed an enemy of the state given his radical commitments, his belief in an international struggle, and the warm reception of his ideas worldwide.

As the US entered World War I the Espionage Act was part of a new set of federal legislation criminalizing dissent. Such laws were deployed within a new and broadened security infrastructure, designed to monitor, infiltrate, and suppress political opposition located within the boundaries of US Empire. This moment of expanding domestic security and militarism also marked the global ascendency of US capitalist hegemony. In this context, social movements 
around the world, like the Mexican Revolution and the class war anarchism of Flores Magón, represented a dramatic and, up until that point, unrivaled challenge to the global capitalist economy. As the United States sharpened its capabilities to control the social and political environments of capital accumulation within an expanding global sphere of influence, the opposition of Flores Magón and other antiracist, anti-imperialist, and anticapitalist figures like him presented radical alternatives to capitalist regimes. Convicted under the new federal legislation, anarchists, socialists, communists, pacifists, and revolutionary nationalists, otherwise separated by deep ideological differences, increasingly found themselves bound together behind the walls of Leavenworth Federal Penitentiary.

This article examines Leavenworth Penitentiary as a convergence space of radical internationalist traditions between 1917 and 1922. It observes that as the United States entered World War I, Mexican revolutionaries like Flores Magón joined other radicals and working-class military prisoners due to new federal laws regulating political dissent. It considers the multiple contradictions and possibilities produced by these encounters, as incarceration threw together prisoners of different races, ethnicities, nationalities, political orientations, and ideologies.

Incarcerated for their resistance to militarism, capitalism, and racism, prisoners transformed Leavenworth into an organizing space, a laboratory for new ideas and tactics, or, as one federal surveillance file called it, "A University of Radicalism." In this way, insurgent prisoners repurposed the space of the prison to engage in the labor of radical knowledge production. The story of Leavenworth offers an episode in which the disciplinary mechanisms of racial capitalism unintentionally produced its own negation. Through a survey of their writings, teachings, cultural productions, and prison records, this article explores an internationalist political imagination that prisoners wrestled with and envisioned. It argues that the convergence spaces of Leavenworth offered a microcosm of antiracist and anticapitalist struggles in the period, reflecting how the color line and the class struggle were understood, experienced, and resisted during this moment. ${ }^{4}$

\section{The Global Production of the Penitentiary}

For most of the twentieth century Leavenworth Federal Penitentiary was the largest maximum-security federal prison in the United States. The struggles contained within the prison walls were prefigured in the production of the space itself. Built as a fort in the 1820s, Leavenworth first operated as an 
outpost for western conquest. The base offered military protection for settlers and merchants trading along the Missouri River, the Oregon Trail, and the Santa Fe Trail, the primary US trade route into Mexico. It became a central "staging area" for the Mexican-American War where thousands of soldiers and volunteers were housed, equipped, and trained. The army sieges that captured Mexican cities like Santa Fe and Los Angeles were headquartered there. Later the Department of the Missouri organized many of its brutal Indian campaigns from the base. After the Civil War, the fort became home to regiments of Buffalo soldiers, squads of Black soldiers who were variously stationed in the Plains, deployed against Native American forces, and later trained for overseas battle in the Philippines. When Leavenworth became a military prison in 1874, among its first prisoners were the original captives of US Empire: Native American men from the Cherokee, Kiowa, Comanche, Cheyenne, Arapaho, and Nez Perce nations; Mexican men from the newly conquered territories; and Buffalo soldiers, many of whom were formerly enslaved or the children of slaves themselves. ${ }^{5}$

Given its readily available pool of prison labor, Ft. Leavenworth was authorized to become a federal penitentiary under the Three Prisons Act. Beginning in 1897, the military prisoners of Ft. Leavenworth were marched two and half miles every morning to the site of the future penitentiary. For twelve hours a day they dug, cleared brush, and extracted building materials from the surrounding environs. Under a blistering Kansas sun, prisoners cut gray stone from the high bluffs overlooking the Missouri River. Those who stepped out of line, slowed down, or stopped were punished with twenty-five-pound irons affixed to their legs. The building blocks of the penitentiary was consequently shaped, carried, and laid by prisoners themselves. From its foundation, Leavenworth's austere landscape was humanized as decades of imprisoned men built the literal walls around themselves. In addition to the construction work, the maintenance, clerical duties, and other jobs like running the electrical generator and practicing medicine in the prison hospital fell to Leavenworth's prisoners. To Congress's delight, this labor regime persisted for decades, keeping the costs of prison operations perennially low. ${ }^{6}$

For several years, steel for the remaining cellblocks lay untouched. Unwilling to hire skilled construction crews, prison officials halted construction. In 1913 thirty-four ironworkers were convicted for their protests of the National Erectors' Association, a brutal employer association. Their conviction was Leavenworth's gain. After fighting low pay, hazardous work conditions, and violent company thugs on the outside, the ironworkers found themselves erecting steel inside Leavenworth's walls for next to no pay while surrounded 
by armed guards in gun towers - which had themselves been built by prisoners under similar conditions of duress. Construction continued until 1927, with prisoners utilizing a penitentiary stone quarry, brickyard, carpentry shop, and stone sawmill among other advanced construction "offices." So impressed with the efficiency of the labor organization at Leavenworth, Henry Ford commissioned Harry R. Hillier from the motion picture department of his Ford motor plant to film the institution in 1919. As Hillier assessed, "I believe there is no community of the same size in the United States, which contains the amount of brains and even genius that the two thousand men in here have."

While maintaining its role as a military prison, Leavenworth Penitentiary became a unique space of control for political radicals after 1917 because of new federal laws criminalizing dissent. In June of that year, Congress passed the aforementioned Espionage Act. ${ }^{9}$ After the United States entered World War I, federal legislation increasingly focused on suppressing antiwar sentiment, both against individual draft dodgers and those organizing broader political opposition. Later amendments to these laws intensified the repression. The Selective Service Act in 1917 mandated compulsory conscription and prosecuted those who avoided it. The Sedition Act of 1918 forbade the use of "disloyal, profane, scurrilous, or abusive language" about the US government, flag, military, and Constitution. ${ }^{10}$

In the wake of World War I, the ongoing Mexican Revolution, and the Russian Bolshevik Revolution in October 1917, these laws along with the creation of the first federal police system as well as the first massive domestic intelligence program produced a new massive security infrastructure. This period constituted the first wartime instance when the government operated prisons to house its own legally defined "civilians." Over two thousand prosecutions occurred under the original Espionage Act, including that of Socialist spokesman and draft opponent Eugene V. Debs and the anarchist intellectual Emma Goldman. In creating new state capacities to legalize the detention, repression, and imprisonment of thousands of Americans for their political beliefs and associations, the expansion of federal government capacities in this period laid the groundwork for the first Red Scare of 1919-20. As the largest and oldest of the three federal prisons, Leavenworth became a central node of this emergent security regime. ${ }^{11}$

The expansion of the prison system and the shifting capacities of the federal government responded to the contradictory movements of capital in the period. ${ }^{12}$ The onset of World War I was a boon to US industrial production, distribution, and transportation, particularly as European powers increased their demand for US-produced war materials such as munitions, guns, and 
airplanes. By early 1917 , Allied powers had purchased over $\$ 2$ billion of such equipment, helping position the United States as the world's primary industrial power. Consequently, demand for production expanded, outstripping the available pool of labor. By 1918, with forty-four million people employed in the formal labor force, industrial production peaked, real wages rose, and workers dramatically enhanced their leverage. Strikes broke out across industries, such as iron, steel, mining, lumber, textile, and a number of wartime industries, significantly among East Coast shipbuilders.

The period produced an emboldened labor movement including political gains by the Socialist Party, anarcho-syndicalist groups, and specific efforts of the Industrial Workers of the World (a.k.a. the Wobblies) to organize a class struggle across the color line. By 1919 approximately one in seven US workers went on strike, with as many as one in four in New York City. Various mechanisms were used to combat the real and potential growth of this class power, including employer subterfuge, raids, brutal strikebreaking by hired thugs, surveillance by private detective agencies like the nefarious Pinkerton National Detective Agency, and assistance or compliance by local law enforcement. In this vein, state laws and new federal legislation such as the Espionage Act explicitly targeted labor militancy. ${ }^{13}$

In practice, the 1917 Espionage Act targeted three main groups (which were by no means mutually exclusive): World War I peace activists and war dissenters; labor organizers (especially foreign-born members of groups like the Wobblies); and Black workers, writers, and cultural producers organizing against Jim Crow racism. As Senator Lee Overman of North Carolina reasoned, the Espionage Act was necessary to stop papers from being circulated "through the South urging Negroes to rise up against white people." Though seemingly discrete actions, efforts to repress labor were deeply entangled with movements to suppress antiracism and promote militarism. ${ }^{14}$

This movement of industrial capitalism was abetted by the geographic expansion of finance capital prior to and after World War I. Financial regulations significantly shifted, and in 1915 President Wilson lifted a ban on US creditors' ability to make private loans to Allied countries. As a result, US investments abroad nearly doubled from $\$ 5$ billion to $\$ 9.7$ billion between 1914 and 1919 . Previously one of the largest debtor nations, the export of money and munitions and the decline of British solvency transformed the political economy of the country and made the United States into a creditor nation for the first time in its history. Thereafter, the United States was newly able to control capital and trade globally, with the increased ability to dictate the terms of its loans and international investments. In this way the United States joined Britain 
as a major regulator of the world capitalist economy, and the central node of capitalist infrastructure began its shift from London to Wall Street. From this position, the United States was poised to overtake Britain and become the dominant economic, military, cultural, and political power in the world, in what would come to be called "The American Century."15

The export of both money and munitions securely tied the interests of US finance capital to an Allied victory and, ultimately, prompted the deployment of US soldiers to support the Allied nations. The peace movement challenged both the expansion of American finance capital overseas and the country's emergent global standing. Therefore, the criminalization of war dissenters by new federal legislation was intended as much to punish individuals as it was designed to ensure investments of US capital abroad and its expanded sphere of influence.

The opposing interests of various factions of capital and their conflicting racial agendas appeared to crystallize with the onset of the war. This could be understood through the newly criminalized social movements of the period. Leavenworth Federal Penitentiary, a container of dissent against racial capitalism and militarism, became a site through which the fluidity of the racial regimes within and across borders was made legible. Between 1918 and 1919, the prison population vastly expanded to house nearly two thousand men, nearly four hundred of whom were foreign nationals. As many of Leavenworth's prisoners believed, the global regimes of racial capitalism were not inevitable. Prisoners came from the powerful social movements of the period and reflected alternative visions to racial capitalism. Though diverse and specific to their contexts, these global movements all held in common a desire for an equitable redistribution of wealth. ${ }^{16}$

The Russian Revolution of 1917 clearly articulated this radical vision. By supporting efforts of self-determination and denouncing the social relations of private property, it offered a bold counter to capitalist visions. Revolutionaries around the planet were inspired to also imagine a new society. From labor movements in Europe and the Americas to the "distant interior of Australia" Irish Catholic sheepshearers "cheered" the Soviet workers' state. In Spain, the years between 1917 and 1919 came to be known as "the Bolshevik biennium," even though most supporters were "passionately anarchist." 17

The year 1917 also marked the creation of Mexico's revolutionary Constitution, one of the most radical and comprehensive in modern political history for its nationalization of resources and sweeping land reforms. In this period, the Ghadar movement against British imperialism in India was also growing, with critical centers in the United States, especially in California and throughout the 
Pacific Northwest. Anticolonial insurgents in Ireland took advantage of their new leverage during World War I to launch a counterattack on occupying forces. By 1917 Irish rebel forces were regrouping after the Easter Uprising rebellion against British colonial forces the prior year. In Niger, the Tuareg and Hausa people continued their extended rebellion against French colonial forces. In 1917 Marcus Garvey opened his first US chapter of his UNIA (United Negro Improvement Association). That year Haitian Caco rebels continued their struggles against US militarism. African American papers like the Messenger would soon deem the US occupation of Haiti "America's India," "America's Corea $[s i c]$ and Ireland." According to the political economist Giovanni Arrighi, such movements represented "the most serious wave of popular protest and rebellion hitherto experienced by the capitalist world-economy." In this period, Leavenworth offered a microcosm of these global waves of rebellion. ${ }^{18}$

\section{University of Radicalism}

Between 1917 and 1922, Leavenworth Federal Penitentiary was occupied by a motley crew of war dissenters, radical labor organizers, foreign-born radicals, and Black militants. Some key figures in this early post1917 period included inmates like Tarknath Das, an Indian leader in the US Ghadar

\section{Figure 2}

Leavenworth New Era, 6.5 (March 28, 1919) La Casa de El Hijo del Ahuizote, Mexico City, Leavenworth Periódicos, File No. 41751 movement; George Andreychine, a Bulgarian socialist and trade-unionist who would go on to have major positions in the Comintern; and Earl Browder, future general secretary of the Communist Party of the USA. Some of the most prominent political prisoners at the time were Wobblies. On September 28, 1917, ninety-seven members of the Industrial Workers of the World (IWW) were convicted of conspiring to obstruct the war by opposing the draft. Those sentenced included figures like "Big" Bill Haywood, a founding member and lead organizer of the IWW; Vicente Aurelio Azuara, a newspaper editor originally from Spain; Peter McEvoy, an iron molder from Ireland; James Slovik, a fisherman from Russia; and Carl Ahlteen, a writer from Sweden. ${ }^{19}$

Ben Fletcher, an African American longshoreman and one of the most talented labor leaders of his time as one of the few Black Wobblies, was also among the convicted. In the period when few African Americans were permitted to join labor unions, Fletcher attempted to shift the racial consciousness of the IWW and of the labor movement more broadly. In an op-ed he penned for the Messenger, Fletcher wrote, "Organized labor, for the most part be it 


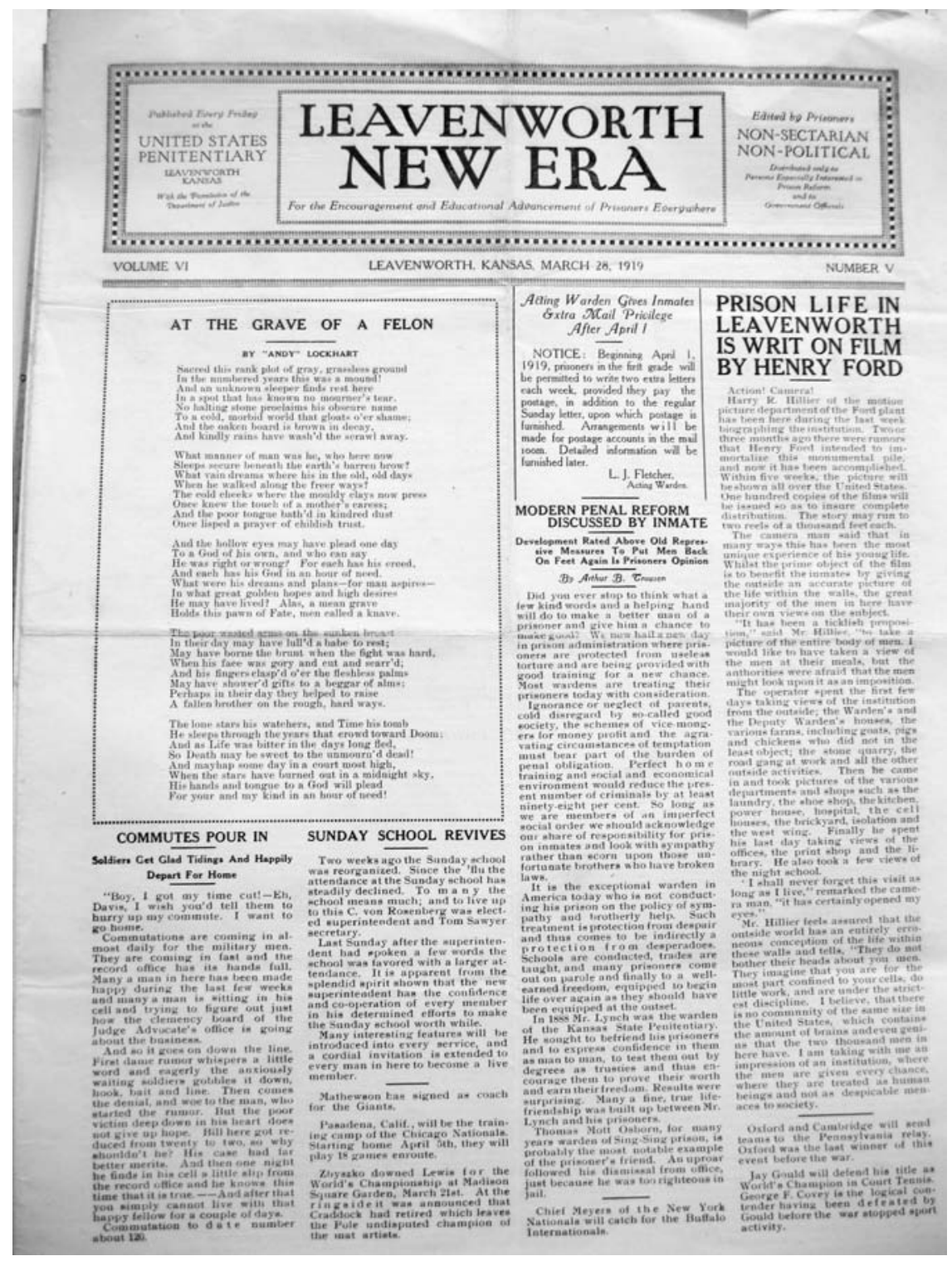


radical or conservative, thinks and acts, in the terms of the White Race." ${ }^{20}$ So concerned about his activities, J. Edgar Hoover, then head of the antiradical General Intelligence Division of the Bureau of Investigation, monitored Fletcher's mail for information about "Negro agitation." Imprisoned Wobblies also included those with overlapping between the membership of the PLM and IWW such as the Mexican-born miner Tomas Martínez. The combination of these figures-Bulgarian communists, Indian Ghadarites, Mexican anarcho-syndicalists, and African American socialists-made for an unusual convergence of radical traditions. In September 1919 the Liberator, a socialist magazine out of New York, published an article by a Leavenworth inmate, which dubbed the prison a "school for revolution." The phrase is useful in describing the repurposing of space within the walls of Leavenworth. ${ }^{21}$

The prisoners wrote, published, and edited a prison newspaper called the Leavenworth New Era. The paper was an innovative source of information, including prison news, gossip, inmate demographics, coverage of the prison baseball league, book reviews, poetry, and even excerpts from other prison newspapers. The British Wobbly Charles Ashleigh wrote regularly about culture and politics. Browder wrote about jazz, culture, and the fallacies of whiteness. Enrique Flores Magón, Ricardo's brother and PLM member, published a regular column called "Mexican Kaleidoscope." In a series of short stories he educated fellow prisoners about the Mexican Revolution.

In one dramatic story titled “The Invader," Enrique Flores Magón described a fictionalized encounter in which elders in a Mexican village educated a young white American man about the causes of the revolution. "Why did you sell your land, your waters, your plows and your beasts?" asks the American. "'They took it all away from us," replies one villager. Following this exchange, a "long deep sobering sigh comes forth from the very bottom of [the villager's] heart; [a] sigh that finds echo in the bosom of all the others." 22 Perhaps such works transformed the thinking of other inmates about Mexico and the plight of Mexicans in the United States. In an open letter to President Warren G. Harding in 1922, fifty-two of the imprisoned Wobblies pleaded their case by making a poignant point about racialized representations, saying "In the capitalist newspaper the I.W.W. is like the Mexican in the movie show; he is always the villain." ${ }^{23}$

The cover story of the April 9, 1920, issue of the Leavenworth New Era describes the success of the Leavenworth night school, a minor university selforganized by the prisoners for the prisoners, with instructors drawn from the ranks of the prison population itself: 
Over six hundred men gathered nightly in the great hall, to pursue their studies under the guidance of teachers, who were also their fellow prisoners. Yet, without any intervention by the officers of the prison, an admirable discipline prevailed. . . the school is their institution; and they were responsible for its order and success. ${ }^{24}$

Classes included automobile mechanics, English, Russian, French, general electricity, mechanical drawing, typewriting, and three classes in Spanish (one of which was taught by Enrique Flores Magón and another by the Spanish Wobbly Vicente Azuara). Four out of five nights were devoted to study. Every Wednesday night, students were shown educational films or slideshows. Prisoners often wrote to the warden's office to order textbooks, foreign language dictionaries, notebooks, and other school supplies. ${ }^{25}$

Aside from the "formal" education of the night school, there were informal and innovative ways in which the prisoners educated each other. Regular lectures were held in the wings of the cellblocks, with inmates crowding corners or craning their ears down from tiers above to hear the lessons. Lectures came from incarcerated lecturers like Allen Broms about propaganda, sociology, Marxism, and political economy. In good weather, Tarknath Das would go outdoors to the "wobbly shed," to join Wobblies like Ralph Chaplin and Ashleigh to discuss the Russian Revolution, poetry, the day's news, and medieval ballads, and he would sometimes deliver speeches about Indian Vendata philosophy. Das also introduced the Dewey decimal system to the prison library, cataloguing over eight thousand volumes. Radical textbooks and pamphlets were brought in by any means possible. Some prison-issued copies of the Bible had been taken by prisoners to the printing plant, gutted, re-bound, and filled instead with the Communist Manifesto. ${ }^{26}$

Prisoners read and passed around other magazines like the Liberator, the Messenger, the Industrial Worker, Regeneration, the Political Prisoner, the Nation, Arizona Labor Journal, the Globe, the Modern Review from Calcutta, and the Workers' Dreadnought out of London. The act of reading often provided a way to transfigure the space of enclosure. "Books!" wrote J. A. McDonald in The New Era. "With Homer we are spectators at the Siege of Troy. We climb Olympus and listen to the congress of the gods. . . We travel over fantastic seas to grotesque lands found only in the geography of the imagination." ${ }^{27}$ Some books from Enrique Flores Magón's personal collection included The Universal Kinship by J. Howard Moore, Death of a Nobody by Jules Romains, Thought in the Russian Revolution by Albert Rhys Williams, and Russia in 1919 by Arthur Ransome. 
One popularly circulated book was his copy of Louise Bryant's Six Red Months in Russia, the firsthand account of Bryant, an American socialist feminist, in the early years of the 1917 Russian Revolution. There Bryant records her conversations with many Bolsheviks, especially Russian feminists like Katherine Breshkovsky and Alexandra Kollontai, who made radical arguments about gender and sexuality, arguing, for instance, that until the revolution could fundamentally transform gender relations and liberate notions of sexuality it could not be truly transformative. Inside Bryant's book is Enrique Flores Magón's name and inmate number. On the next page is a note he has written to the other prisoners, "Please take good care of this book, do not write in its pages, and return it to its owner as soon as you are through reading it, for there are others who want to read it and are waiting for their turn." Given the unusually generous (albeit contested) space the PLM gave to questions of feminism and gendered discourse, the inclusion of the book in Enrique's library was unsurprising. More remarkable is the book's apparent wide circulation, and the degree to which it was in demand by other prisoners. ${ }^{28}$

From this type of education, it is no surprise that radical action happened inside the walls as well. Strikes, work stoppages, and social protests occurred with frequency. On May Day in 1919, the prisoners held a march/celebration inside the prison. Successfully appealing to the warden that the first of May, International Workers' Day, was as sacred to radicals as religious holidays were to practicing observers, the prisoners gained a May Day celebration with little interference. Prisoners turned their state-issued jackets inside out, exposing the red flannel lining. They hoisted magazine cutout images of Vladimir Lenin and Abraham Lincoln on broomstick handles. The day began with a singing of "The Internationale," an anthem that communists, socialists, anarchists, and all "prisoners of starvation" and "wretched of the earth" could sing together. The program also included a discussion of revolutionary methods, a quote contest between the anarchists and the socialists, and an open-air parade. The program gives a sense of the political tendencies within the prison, as well as the camaraderie and political dialogues among the prisoners. The planned program of the day was as follows:

\section{$9 \mathrm{am}$}

1. “The International," by all Revolutionists.

2. "Dead March," by Russian chorus.

3. Address: "Karl Marx," by ...

4. "The Red Flag," by all Reds.

12 noon

5. Open Air Parade Through Wire City. 
6. "Hold the Fort," by I.W.W. choir.

7. Address: "The First of May," by ...

8. "Stung Right," by all Reds.

$6 \mathrm{pm}$

9. Open Air Singing Between No. 6 and No. 7 Barracks.

10. I.W.W. vs. Socialist-Quotes Contest.

11. Address: "The American Way" by ...

12. Discussion of Revolutionary Methods.

13. “The Marseillaise," by all Reds ${ }^{29}$

While the marches, night schools, lectures, and publications produced a unique political space, Leavenworth, of course, remained a punitive disciplinary institution. Prisoners were subjected to brutal treatment, suffering malnourishment, harsh discipline, extended periods of solitary confinement, and inadequate medical care. Prison guards took out personal vendettas against prisoners for their political beliefs. The Wobblies were often subjected to weeks in what was referred to as the "torture chamber," otherwise known as "the hole," for their associations and protests. Men were particularly punished for their stance as conscientious objectors.

The labor and IWW leader Elizabeth Gurley Flynn recounted the gruesome treatment of a dozen Mennonite men who were serving long sentences for their "uncompromising opposition to warfare." Because of their refusal to join the military and wear army uniforms, they were disgraced and tortured by prison guards. Their beards were cut and buttons were affixed to their uniforms in defiance of their religious custom. They were made to sleep on the concrete with no blankets at night. During the day they were "manacled to bars so high they could barely touch the ground." With intense pressure, the cuffs dug into their wrists, swelling and eventually cracking the skin of their hands, spilling blood down their arms and onto their bodies. Two of the men, Joseph and Michael Hofer, died as a result of this extreme torture. Adding insult to injury, the prison returned the bodies of the men to their pacifist Mennonite communities in South Dakota dressed in the army uniforms that the men had refused to wear in life. Their example illustrates the breadth of punishment in Leavenworth from the extreme to the minutia. ${ }^{30}$

There were other ways in which the prison itself was a disciplining institution, particularly in terms of race and gender. This was perhaps most clearly seen in the incarceration of the famed boxer Jack Johnson. Johnson had risen to fame in Black communities and reached notoriety in many white communities when he defeated the "Great White Hope" Jim Jeffries in 1910. In that defeat, the myth of white racial supremacy was profoundly ruptured. Films 
of Johnson overpowering white boxers were made illegal in some states after violent white mobs rioted across the country after viewing them. Johnson flaunted his victory and his wealth in the face of white rage, openly dating and marrying white women, many of whom were sex workers.

Eventually, Johnson was convicted under the Mann Act in 1912, a law prohibiting the trafficking of "white slaves" across state lines, particularly white women for "prostitution or debauchery, or for any other immoral purpose." At this time, the regulation of sexuality through such laws criminalizing prostitution and interracial relationships enabled the growth of the federal prison system and local convict-lease systems, and gave credence to deputized bands of vigilantes and lynch mobs. ${ }^{31}$

After his conviction, Johnson and his then wife fled the country, eventually winding up in Mexico. There, Johnson also began to sympathize with the possibilities of revolutionary Mexico. He compelled other African Americans to follow suit to "Latin America, the garden of the world," which he reasoned "offers us all the golden privileges of a land that has never known racial prejudice." Mexico, he wrote, "was willing not only to give us the privileges of Mexican citizenship, but will champion our cause." According to FBI records, the 1919 films of Johnson in Mexico City, dressed to the nines, announcing that he, an African American man, was a member of the finest clubs in the city, caused jubilant celebrations and the possible "incitement" of African Americans in the United States. In the face of Jim Crow segregation, the image of Johnson symbolically upending US racial codes fired people's imaginations. In crossing back over the Mexican border in 1920, Johnson was arrested and sent to Leavenworth. ${ }^{32}$

Johnson's days in prison were full. He conducted daily financial affairs through telegrams, wrote an autobiography, invented and patented a new tool, staged a public boxing exhibition in the prison with the warden's blessing, and arranged his postrelease boxing schedule. For a while, his official duty was to maintain the prison baseball yard. Through this work he would have encountered prisoners such as Roy Tyler. Tyler was much younger than Johnson. He became his sparring partner and developed a relationship that would carry on in letters after Johnson was released. On that baseball field, Tyler discovered his own athletic talent. He was effectively drafted into the Negro Leagues when the head of the organization became his parole sponsor. After his team lost a major championship, Tyler was marooned in Indiana and found work as a porter, a car washer, and other non-sports-related jobs. $\mathrm{He}$ was quickly detained on a trumped-up charge and returned to Leavenworth for violating his parole. ${ }^{33}$ 
Tyler was never listed as a "political prisoner," but perhaps this is a misnomer. Tyler was involved in another long-forgotten event in that global year of 1917. In August the Third Battalion of the Twenty-Fourth Infantry mutinied against its officers in Houston, Texas. This was a regiment of Buffalo Soldiers, all Black men, one whose history reminds us of the United States' vast and contradictory imperial ambitions. In its history, the Twenty-Fourth Infantry had been deployed to Cuba during the Spanish-American War in 1898. Later the same regiment was sent to the Philippines as part of the Philippine-American War, where Black soldiers, or "smoked Yankees" as they were called, had to newly consider their support in waging an imperialist war against the Filipinos. In 1916 the regiment entered Mexico to assist General John J. Pershing's search for Pancho Villa, where it might have encountered a number of African Americans who had defected to that country. ${ }^{34}$

In 1917 the battalion was stationed in Houston during construction of a base there. Racial tension in the city was high, with white Houstonians unwelcoming of this Black regiment. On the evening of August 23, 1917, a Black soldier attempted to stop the assault of a Black woman by white officers and was subsequently arrested. Later that day, when another Black soldier, Charles W. Baltimore, inquired about the arrested man, he was brutally beaten by white officers. A rumor spread that Baltimore had been killed. Against the backdrop of violence, humiliation, threats of white mobs, and the specter of lynchings, the rumor set off anger among the Black soldiers. Around one hundred and fifty members of the regiment took up arms and marched to the center of town, opening fire on the police station and killing fourteen people. For the crimes of murder and mutiny, nine soldiers were executed by hanging. Over forty were sentenced to Leavenworth. Like Tyler, many were young men. And like Tyler, many were paroled, picked back up, and sent back to Leavenworth in a higher frequency than other political prisoners. Like many of the other men in his unit, Tyler's series of mug shots shows him progressively aging in prison, marking an early moment in the racialization of the penitentiary. ${ }^{35}$

\section{The Death of José Martínez}

The documents for Roy Tyler's parole add a curious footnote to the story of Leavenworth Penitentiary. In support of his parole, Tyler was praised for protecting prison guards from other inmates. In one instance, Tyler was credited with preventing "a gang of I.W.W. prisoners" from harming the deputy warden and other officers. In another, he was awarded special recognition for helping to capture another prisoner, José Martínez. The warden recounts the incident as follows: 
On November 14th, when Joe [sic] Martinez, a Mexican murderer, killed Captain Andrew Leonard and wounded six guards by stabbing them, [Roy] Tyler voluntarily entered the underground coal bunker and took a dagger from Martinez. ${ }^{36}$

For his help, the warden offered Tyler "the highest commendation of the prison officials." Despite this praise, Tyler's parole was denied. While the episode grew stale in the pages of Tyler's parole files, the particular entanglement between Tyler and Martínez highlights the unfortunate convergences enabled by the prison. ${ }^{37}$

On November 14, 1922, José Martínez had "fashioned the knife" from a piece of steel and attacked several guards, including the captain, whose wounds proved fatal. The guards responded to the attack with gunfire. Injured by gunshot wounds, Martínez staggered off the prison yard into the penitentiary coal shed, refusing to exit. A tense standoff ended after Tyler entered the "bunker," disarmed Martínez, and enabled a guard to strike him in the head with a block of coal. Martínez was sent to the prison hospital while the captain was delivered to the morgue. The incident provoked a flurry of letters and telegrams. When a Montana deputy inquired whether his friend, Captain Andrew Leonard, had survived the attack, the Leavenworth warden curtly replied that the captain had indeed been "fatally stabbed by [a] crazed Mexican." 38

Martínez was a convicted murderer serving twenty-five years in Leavenworth Federal Penitentiary. He had killed the much feared and respected captain of the guards, Andrew "Bull" Leonard, a Spanish-American War veteran employed at the prison since 1900. To a public accustomed to dime novels, silent films, and new detective fiction, the story of a violent convict attempting escape would have been exciting albeit conventional. The fact that Martínez was Mexican enabled journalists to confirm readily available racial narratives about Mexican bloodthirst and sociopathy. Headlines declared "A Mexican Ran Wild and Killed," and "Mexican Shot after Stabbing Seven Guards." The story was both scintillating enough to land on the front page of the Kansas Hutchinson News and sufficiently mundane to be tucked on page 6 of the New York Tribune. ${ }^{39}$

Mexican people were increasingly maligned in the press and popular culture as US interests in Mexican land, resources, and labor expanded. Routinely depicted as bloodthirsty savages, prideful simpletons, or gun-toting madmen in need of pacification, this discursive violence profoundly shaped popular imaginaries just as it helped shape public policy. Prisoners in Leavenworth were not immune from its reach. One prisoner's account of the attack described Martínez as "a simple pelado (a bum)" who snapped when asked by a guard to remove his hat. This observer suggested that the guard simply "didn't understand how 
proud a Mexican Indian can be of a hat, even a battered old prison-issue straw sombrero." Both inside and outside the penitentiary, mediated through such depictions, Martínez was not just a crazed prisoner but the fulfillment of a mass-produced fantasy: a wild murderous representative of his race. ${ }^{40}$

Within days of the prison yard attack, the story disappeared from headlines. While Martínez lay dying in the prison hospital, another prisoner's dramatic story took its place. On November 22, 1922, Ricardo Flores Magón was found dead in his cell. Beloved by labor leaders, anarchists, socialists, and workers alike, Flores Magón's death received attention across the globe. From London to Mexico City to the White House, workers expressed outrage in articles, letters, and mass demonstrations. Flores Magón's closest comrade and political ally in prison, Librado Rivera, a fellow anarchist and PLM member, alleged that he had seen bruises around Ricardo's lifeless neck, suggesting that Flores Magón had been strangled to death. Rivera also noted that Flores Magón had been moved into a cell out of earshot the night before his corpse was discovered. ${ }^{41}$

While some doubted claims that Flores Magón had been assassinated, others like the socialist labor leader Eugene V. Debs accused the prison of committing slow murder. Writing in the New York Call, Debs echoed the concern of many of Flores Magón's friends and supporters, arguing that he had been killed as a result of medical neglect and the indifference of prison officials. An op-ed reprinted in several Mexican papers similarly described the circumstances leading up to Flores Magón's death as simply "salvajismo inconcebible" (inconceivable savagery). ${ }^{42}$

Although separated by measures of public sentiment and international concern, the lives and fates of Ricardo Flores Magón and José Martínez were curiously linked. Flores Magón had been a leader and friend to many in the penitentiary, particularly to a growing number of Mexican prisoners like Martínez. He was regarded as a political mentor, a man who could compellingly lecture about philosophy, poetry, and Mexican history. He was also a much loved counselor, letter writer, and confidant for many men. A Nation article written during Flores Magón's incarceration at McNeil Island Federal Penitentiary, just prior to his transfer to Leavenworth, reported that "there was not a Mexican worker in that prison-and there were many-who would not have laid down his life to give Flores Magón a free and easy hour." ${ }^{43}$ This insight illuminates the likely solidarity between Flores Flores Magón and Martínez.

There were multiple spaces where the two men could have encountered each other: in the Leavenworth library where Flores Magón worked as a librarian; in the prison yard where inmates circulated; by the rock pile that Flores Magón and his comrades dubbed the "campus" where they gathered daily 
for debate and conversation, and where between November 25, 1919, and February 3, 1920, Martínez was assigned to work; or possibly in the mess hall where all the prisoners ate their meals together under heavy surveillance. Not long before Flores Magón's death and Martínez's attack, a strike broke out in the mess hall. The prisoners, fed up with a nauseating diet of boiled parsnips, first silently and then raucously expressed their disapproval. This "food riot" significantly upset the guards. Instead of responding directly to the protest, the guards used the opportunity for retribution and sought ways to break the spirit of the prisoners. ${ }^{44}$

The guards selected prison leaders and educators, many of whom had nothing to do with the "riot." Flores Magón, an older man, in frail health with diminishing eyesight, is reported to have been among those singled out for punishment. A former Mexican railroad worker, Joseph Savas Reza, witnessed the assault. He recounted that Leonard beat the enfeebled Flores Magón while Martínez looked on helplessly. Days later, when Martínez attacked Leonard and several other guards, it was understood by Reza and subsequently by other historians as retribution for Leonard's attack on Flores Magón. Tellingly, Librado Rivera came to aid the injured Martínez during the attack. One eyewitness reported that José Martínez even wept on Rivera’s shoulder before he was taken to the prison hospital. ${ }^{45}$

According to his prison record, Martínez was not the rash man, driven by pride, the "simple pelado" as described. In the years prior to the attack, he had incurred four minor violations: two for smoking a cigarette, one for not stopping when told, and another for not removing his clothes when ordered. A March 1921 physician assessment found that Martínez "does not give any evidence of mental unbalance," and a February 1921 note from the warden to the War Department indicates that Martínez's "conduct during confinement has generally been excellent." In a 1920 letter for clemency to the secretary of war, Martínez himself expressed doubt about his own survival in the prison, writing, "As for me, I very much doubt to outlive my sentence, as I have been very sick during my confinement in this prison." It is difficult to characterize Martínez's decision to attack the Leavenworth guards as an impulsive response to a personal insult. Plausibly, the honor he was defending was not even his own. ${ }^{46}$

Martínez was brought to the infirmary with gunshot wounds to the knee and stomach and a severe head injury. His hospital record indicates that for five days he was administered the same treatment: aspirin. Not until the fifth day was he given the additional treatment of "ice bags to abdomen." After killing one guard and attacking six others, Martínez lay in the prison hospital 
with a growing fever and blood poisoning spreading throughout his system, with only aspirin and ice to treat him. He succumbed to his injuries fifteen days later, with the official cause of death reported by prison officials as "Septicemia, following gunshot wound, abdomen." In contrast to Flores Magón, there was no media scrutiny following the death of Martínez. He was buried at Leavenworth, in the Kansas soil, alongside other prisoners with no family to claim them. On the note indicating whom to contact in case of illness and emergency, the typist entered "noboyd $[s i c] . "{ }^{47}$ There was no memorial for Martínez, a common fate for many Leavenworth prisoners. In his poem "At the Grave of a Felon," fellow prisoner "Andy" Lockhart offered a eulogy for the many men like Martínez unceremoniously buried in the prison grounds:

The poor wretched arms on the sunken breast ... Perhaps in their day they helped to raise I A fallen brother on the rough, hard ways ... And as Life was bitter in the days long fled / So Death may be sweet to the unmourn'd dead! ${ }^{48}$

José Martínez had come to the United States from Chihuahua, Mexico, where Pancho Villa had briefly served as a provisional governor (1913-14) and where American publishing tycoon William Randolph Hearst owned the million-acre Babicora Cattle Ranch. A leatherworker by trade, Martínez had been a bullfighter in his youth, a laborer in Sacramento, California, and El Paso, Texas, and possibly also a field hand in Plainview, Kansas. His immigration form asked if he was educated and healthy, and if he was an anarchist, a new category prompted by the growing popularity of Flores Magón and fellow members of the PLM. Martínez lived in El Paso, Texas, a notoriously racist town with a large Mexican labor force and a history of rampant lynchings, beatings, and disappearances by civilians and deputized Texas Rangers alike. In 1916 twenty Mexican people were doused with kerosene and burned alive, an incident that incensed Mexicans on both sides of the border and provided the rallying cry for Pancho Villa's invasion of Columbus, New Mexico. ${ }^{49}$

Prior to his time in Leavenworth, Martínez himself had been a soldier of US Empire. He was incarcerated at Leavenworth after serving in Company $\mathrm{M}$ of the 125th Infantry, part of the Expeditionary Forces in France during World War I. Alongside many unwilling and suspicious Mexican workers in Texas, Martínez had enlisted in the US Army in 1917. Indeed, one of the few buildings in El Paso that did not carry a "No Mexicans Allowed" sign was the US Army draft office. In World War I, as in other wars, the contradictions of US racial capitalism came to bear on the sudden comradeship of sworn enemies. Americans served alongside Mexicans when not long before, they 
had fought against them. In France, Martínez was involved in a fight with a superior officer, killing the officer in what he characterized as an act of selfdefense. After being court-martialed in France, Martínez was sentenced to the military prison in Leavenworth, Kansas. There, to his surprise, he would come to meet and defend Flores Magón, in an unanticipated transnational alliance produced by the space. ${ }^{50}$

Martínez defended the Mexican Revolutionary figure who had offered one of the earliest and most trenchant critiques of American imperialism in the twentieth century. In doing so, Martínez had unwittingly entered a struggle with global dimensions. Ostensibly, there was much in common between Martínez and Roy Tyler, the Houston mutineer who disarmed him. Both men had enlisted in the military defense of the United States. Both had faced racism from inside and outside their ranks. Both had consequently found themselves condemned to the same military prison. But the common experience of incarceration did not ensure that they shared the same political commitments. While Leavenworth Penitentiary enabled a unique convergence of radical traditions and provided a space for productive and vibrant dialogue, this by no means guaranteed that all prisoners found common cause or shared affinities between themselves. Such alliances would need to be built and organized. ${ }^{51}$

\section{Antiracist Internationalism}

In the years during and after World War I, radical movements, inside and outside the prison, were grappling with the parallel formations of racism and capitalism, although few large-scale movements could successfully theorize their congruity. However, revolutionaries like Ricardo Flores Magón were uniquely positioned to understand how capital crossed borders and linked the destinies of those it dispossessed.

Having been situated on both sides of the US-Mexico border, Flores Magón knew firsthand the difficulties of organizing transborder, transnational, and interracial solidarities. He had witnessed how the beatings, lynchings, and mischaracterizations of both Mexican and Black workers prevented solidarities from forming across the entire working class. Although he witnessed the persistence of many of these racist divisions within Leavenworth Penitentiary, for Flores Magón, such antagonisms were not inevitable. The struggle against racism, he believed, was simultaneously a struggle against capitalism. He wrote, "Capitalism foments racial hatred so that the peoples never come to understand each other, and so it reigns over them." Racism, in his analysis, was a conscious strategy by "the millionaires, the big businessmen, [and] the 
financial bandits" to "open abysses between the diverse races and nationalities, and in this manner to ensure their empire." 52

A global revolutionary movement, in his estimation, needed to confront this racist and imperialist strategy. ${ }^{53}$ In opposing international capital and practices of racialization, he proposed that the Mexican Revolution could inspire new global visions of liberation across the color line. Accordingly, he consistently sought to internationalize the struggle, which he believed had found an early expression in Mexico. He reminded the Mexican workers that their struggle, "the struggle of humanity," was global:

Millions of intelligent eyes contemplate you from across the oceans, from other continents, from other lands, with the same emotion that awaits a life or death decision, because, know it well Mexican workers, because your triumph will be the dawn of a new day for all of the oppressed of the Earth, just as your defeat will result in the tightening of the chains on every worker on Earth. ${ }^{54}$

In his years at Leavenworth, Flores Magón helped transform the federal penitentiary into a university of radicalism. Here, anarchists, communists, nationalists, and pacifists produced new affinities and new understandings. In the writings, readings, teachings, and friendships formed in this convergence space, Flores Magón and other self-professed radicals, alongside imprisoned working-class soldiers of color, were able to confront the expanse and limitations of various radical traditions. But despite his hope for an alternate way of being, he also faced the limits of solidarities produced within the confines of capitalist white supremacy. In one of his final letters, he recalls the Mexican landscape, its flowers and skies, whose "beauty" he hopes he will be blessed with before too long. His thoughts drift from the Mexican cliffs to the US borders beyond the northern shores, on which "lay scattered the wreckage of so many hopes of mine." He concludes with the final tragic lines, "I meant well, my blonde brothers, I meant well, but you could not understand me." 55

If the color line could penetrate prison walls, a movement confronting it would need to do the same, defying partitions and traversing borders alike. This was perhaps a thought that preoccupied Flores Magón at the end of his life. Before he died in a cold Kansas cell, he dreamed of the cliffs and skies of Mexico, hoping his brothers to the North could one day understand him. ${ }^{56}$ 


\section{I American Quarterly}

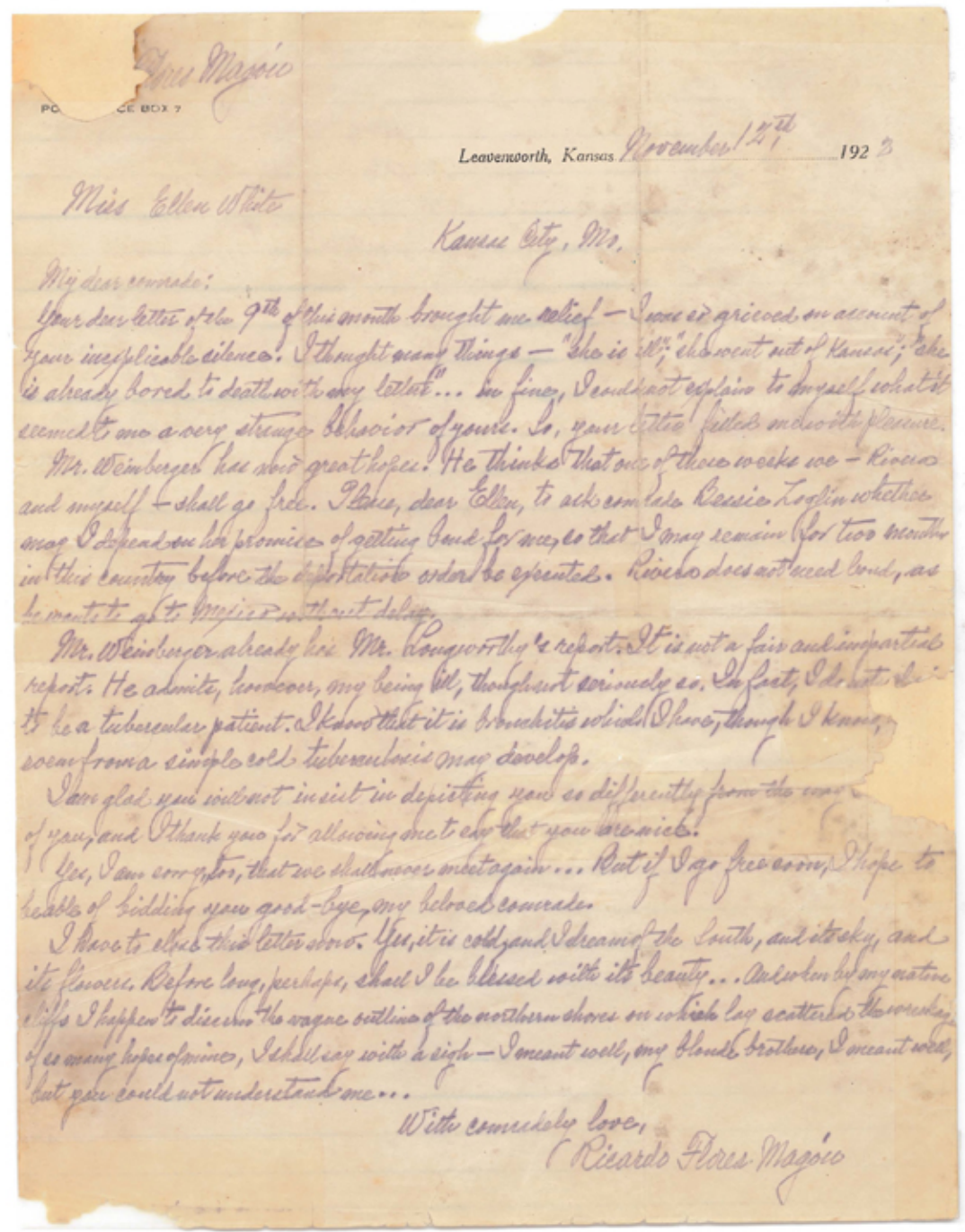

\section{Figure 3}

Ricardo Magón’s final note to “Ellen White”, November 12, 1922, Ricardo Flores Magón Collection, International Institute for Social History (Amsterdam, NI)/ Courtesy of Jacinto Barrera Bassols 


\section{Notes}

Many thanks to the American Quarterly editors Macarena Gómez-Barris, Licia Fiol-Matta, Sarah Banet-Weiser, Nic John Ramos, and Paula Dragosh, and also to Jacinto Barrera-Bassols, Michael Cucher, Elizabeth Esch, Diego Flores-Magón, Taj Robeson Frazier, Alan Eladio Gòmez, Nicole Guidotti-Hernàndez, David Harvey, Cindi Katz, George Lipsitz, Alex Lubin, Maria Elena Martinez, Hugo Sergio Sànchez Mavil, S. Ani Mukherji, Paul Ortiz, Steven Osuna, David Roediger, Stephen Spence, Shelly Streeby, and Devra Weber for their critical feedback and support. Special thanks to Jordan T. Camp, Ruth Wilson Gilmore, Robin D. G. Kelley, Laura Pulido, and Marcus Rediker.

1. Ward S. Albro, Always a Rebel: Ricardo Flores Magón and the Mexican Revolution (Fort Worth: Texas Christian University Press, 1992); Emma Pèrez, The Decolonial Imaginary: Writing Chicanas into History (Bloomington: Indiana University Press, 1999), 56.

2. Ricardo Flores Magón and Librado Rivera, "Manifesto to the Anarchists of the Entire World and to the Wonders in General." Reprinted in Chas Bufe and Mitchell Cowe Verter, eds., Dreams of Freedom: A Ricardo Flores Magón Reader (Oakland, CA: AK Press, 2005), 145.

3. Paul W. Keve, Prisons and the American Conscience: A History of U.S. Federal Corrections (Carbondale: Southern Illinois University Press, 1991), 7. For debates around Flores Magón's death, see Andrew Grant Wood, "Death of a Political Prisoner: Revisiting the Case of Ricardo Flores Magón,” A Contra corriente 3.1 (2005): 38-66.

4. Quoted in Theodore Kornweibel, "Seeing Red": The Federal Campaign against Black Militancy, 19191925 (Bloomington: Indiana University Press, 1998), 160. The conceptualization of a "university of radicalism" is indebted to key texts in American and ethnic studies, including Alan Eladio Gòmez, "Nuestras Vidas Corren Casi Paralelas": Chicanos, Independentistas, and the Prison Rebellions in Leavenworth, 1969-1972,” Latino Studies 6 (2008): 64-96; Sarah Haley, “'Like I Was a Man': Chain Gangs, Gender, and the Domestic Carceral Sphere in Jim Crow Georgia," Signs: Journal of Women and Culture in Society 39.1 (Autumn 2013): 53-77; Laleh Khalili, Time in the Shadows: Confinement in Counterinsurgencies (Stanford, CA: Stanford University Press, 2012). Critical works that frame transnational struggles related to the Mexican Revolution include Shelley Streeby, Radical Sensations: World Movements, Violence, and Visual Culture (Durham, NC: Duke University Press, 2013); and David Luis Brown, Waves of Decolonization: Discourses of Race and Hemispheric Citizenship in Cuba, Mexico, and the United States (Durham, NC: Duke University Press, 2008).

5. Mary Bosworth, Explaining U.S. Imprisonment (Los Angeles: Sage, 2010), 58; Mario Barrera, Race and Class in the Southwest: A Theory of Racial Inequality (Notre Dame: University of Notre Dame Press, 1979), 11-16; Jessica Enoch, Refiguring Rhetorical Education: Women Teaching African American, Native American, and Chicanola Students, 1865-1911 (Carbondale: Southern Illinois University Press, 2008), 77; David Wallace Adams, Education for Extinction: American Indians and the Boarding School Experience, 1875-1928 (Lawrence: University Press of Kansas, 1995), 36-38; Spencer Tucker, The Encyclopedia of North American Indian Wars, 1607-1890: A Political, Social, and Military History (Santa Barbara, CA: ABC-CLIO, 2011), 289; Irene Schubert and Frank N. Schubert, On the Trail of the Buffalo Soldier II: New and Revised Biographies of African Americans in the U.S. Army, 1866-1917 (Lanham, MD: Scarecrow, 2004), 16, 49, 211, 286; Willard B. Gatewood, "Smoked Yankees" and the Struggle for Empire: Letters from Negro Soldiers, 1898-1902 (Fayetteville: University of Arkansas Press, 1987), 228; Jodi A. Byrd, The Transit of Empire: Indigenous Critiques of Colonialism (Minneapolis: University of Minnesota Press, 2011), 148, 222.

6. Keve, Prisons and the American Conscience, 36, 53-56, 141; Tapan K. Mukherjee, Tarknath Das: Life and Letters of a Revolutionary in Exile (Calcutta: National Council of Education, Bengal, 1998), 144-45; “The Dynamiters Convicted,” Independent 74 (January-March 1913), 3.

7. Louis Adamic, Dynamite: A Century of Class Violence in America, 1830-1930 (1934; rpt. London: Rebel, 1984), 110-14; Marilyn D. McShane and Frank R. Williams III, eds., Encyclopedia of American Prisons (New York: Garland, 1996), 342-43.

8. "Prison Life in Leavenworth Is Writ on Film by Henry Ford," Leavenworth New Era 6.5 (March 28, 1919), La Casa de El Hijo del Ahuizote, Mexico City, (CHA) File No. 41738.

9. Zaragosa Vargas, Crucibles of Struggle: A History of Mexican Americans from Colonial Times to the Present Era (New York: Oxford University Press, 2001), 189; Mukherjee, Tarknath Das, 143-44; Stephen M. Kohn, American Political Prisoners: Prosecutions under the Espionage and Sedition Acts (Westport, CT: Praeger, 1994), 7; Keve, Prisons and the American Conscience, 7. 
10. Kohn, American Political Prisoners, 7-9.

11. Bosworth, Explaining U.S. Imprisonment, 56-57; Kohn, American Political Prisoners, 7; Keve, Prisons and the American Conscience, 141.

12. This materialist analysis of prison expansion follows the lead of Ruth Wilson Gilmore, Golden Gulag: Prisons, Surplus, Crisis, and Opposition in Globalizing California (Berkeley: University of California Press, 2007).

13. Richard Hofstadter, The American Political Tradition and the Men Who Made It (New York: Vintage Books, 1989), 341-42; Barbara Foley, Spectres of 1919: Class and Nation and the Making of the New Negro (Urbana: University of Illinois Press, 2003), 8-36; Jeremy Brecher, Strike! (Boston: South End, 1997), 116; Melvin Dubovsky, We Shall Be All: A History of the Industrial Workers of the World (Urbana: University of Illinois Press, 1988), 376-425; Odd Arne Westad, The Global Cold War: Third World Interventions and the Making of Our Times (Cambridge: Cambridge University Press, 2007), 16-17.

14. Bosworth, Explaining U.S. Imprisonment, 56-58. Quoted in Kohn, American Political Prisoners, 8.

15. Hofstadter, American Political Tradition, 341-50; Stephen Broadberry and Mark Harrison, The Economics of World War I (New York: Cambridge University Press, 2005), 334; Cedric J. Robinson, Forgeries of Memory and Meaning: Blacks and the Regimes of Race in American Theater and Film before World War II (Chapel Hill: University of North Carolina Press, 2007), 237; Howard Zinn, A People's History of the United States (New York: Harper Collins, 2010), 362-64.

16. Robinson, Forgeries of Memory and Meaning, 237.

17. Ani Mukherji, "The Anticolonial Imagination: Migrant Intellectuals and the Exilic Productions of American Radicalism in Interwar Moscow, 1919-1939" (PhD diss., Brown University, 2011); Eric Hobsbawm, The Age of Extremes: A History of the World, 1914-1991 (New York: Random House, 1994), 66.

18. Maia Ramnath, From Haj to Utopia: How the Ghadar Movement Charted Global Radicalism and Attempted to Overthrow the British Empire (Berkeley: University of California Press, 2011); Seema Sohi, "Echoes of Mutiny: Race, Empire, and Indian Anticolonialism in North America" (PhD diss., University of Washington, Seattle, 2008); Glenda Gilmore, Defying Dixie: The Radical Roots of Civil Rights, 1919-1950 (New York: W. W. Norton, 2008), 24; Priscilla Metscher, James Connolly and the Reconquest of Ireland (Minneapolis: University of Minnesota Press, 2002), 182-200; Kimba Idrissa, "The Kawousan War Reconsidered," in Rethinking Resistance: Revolt and Violence in African History, ed. Jon Abbink et al. (Leiden: Koninklijke Brill, 2003), 191-217; Giovanni Arrighi, The Long Twentieth Century: Money, Power, and the Origins of Our Times (London: Verso, 2010), 65.

19. National Archives, Central Plains Region, RG 129 Records of the Bureau of Prisons, boxes 510, 525, 526, 534, 554. Hereafter cited as NA, BP.

20. Kornweibel, "Seeing Red," 157-59; Irwin Marcus, "Benjamin Fletcher: Black Labor Leader," Negro History Bulletin 35 (October 1972): 131-40.

21. NA, BP, box 510, 12895; Socialist C.O., "May Day in Ft. Leavenworth," Liberator 2.6 (Serial No. 16), June 1919.

22. Earl Browder, "Values in Music," Leavenworth New Era 5.7 (February 20, 1920), File No. 41746, CHA; Enrique Flores Magón, “The Invader," Leavenworth New Era 5.7 (February 20, 1920), File No. 41746, CHA.

23. Industrial Workers of the World, "An Open Letter to President Harding. From 52 Members of the I.W.W. in Leavenworth Penitentiary Who Refuse to Apply for Individual Clemency" (Chicago: General Defense Committee, 1922).

24. Superintendent, "Our School," Leavenworth New Era 7.7 (April 9, 1920), File No. 41751, CHA.

25. Ibid.; NA, BP, boxes 510, 525, 526, 534, 554.

26. W. Dirk Raat, Revoltosos: Mexico's Rebels in the United States (College Station: Texas A\&M University Press, 1981), 285; H. Austin Simons, "The U.S. Revolutionary Training Institute," Liberator 19, September 1919, 42-44; Mukherjee, Tarknath Das, 150, 147.

27. J. A. McDonald "The White Magic of Books," Leavenworth New Era 5.48 (January 30, 1920), File No. 41745, CHA; NA, BP, box 2, 10, 16, 17, 18.

28. Pèrez, Decolonial Imaginary, 63-71. For a broader context in which these conversations did and did not occur, see Nicole M. Guidotti-Hernández, Unspeakable Violence: Remapping U.S. and Mexican National Imaginaries (Durham, NC: Duke University Press, 2011), 11.

29. Socialist C.O., "May Day in Ft. Leavenworth."

30. Elizabeth Gurley Flynn, The Rebel Girl: An Autobiography, My First Life (1906-1926) (New York: International Publishers, 1973), 255; Mukherjee, Tarknath Das, 146; Paul Alexander and Glen Stassen, Peace to War: Shifting Allegiances in the Assemblies of God (Telford: Cascadia, 2009), 135-36. 
31. NA, BP, box 2, Inmate No. 15461; Randy Roberts, Papa Jack: Jack Johnson and the Era of White Hopes (New York: Free Press, 1983); Theresa Runstedtler, Jack Johnson, Rebel Sojourner: Boxing in the Shadow of the Global Color Line (Berkeley: University of California Press, 2012), 232-33; Khalil Gibran Muhammad, The Condemnation of Blackness: Race, Crime, and the Making of Modern Urban America (Cambridge, MA: Harvard University Press, 2010), 133.

32. Gerald Horne, Black and Brown: African Americans and the Mexican Revolution, 1910-1920 (New York: New York University Press, 2005), 33.

33. NA, BP, box 467, File 12276.

34. Robert V. Haynes, A Night of Violence: The Houston Riot of 1917 (Baton Rouge: Louisiana State University Press, 1976); Gatewood, "Smoked Yankees."

35. Martha Greuning, "Houston," Crisis Magazine, November 1917.

36. “Case Summary of Federal Parolee," September 13, 1932, NA, BP, box 467, File 12276.

37. Ibid.

38. "A Mexican Ran Wild and Killed," Hutchinson News, November 14, 1922, 1; "Mexican Shot after Stabbing Seven Guards," Baltimore Sun, November 15, 1922, 9; "Convict Kills Guard, Stabs 6 Others; Dying," New York Tribune, November 15, 1922, 6; Telegram from Biddle to G. E. Herron, Deputy Sheriff, Havre Montana, November 16, 1922, NA, BP, box 554, Inmate No. 13396.

39. Kenneth M. LaMaster, U.S. Penitentiary Leavenworth (Charleston, SC: Arcadia, 2008), 100; Robinson, Forgeries of Memory and Meaning, Nan Enstad, Ladies of Labor, Girls of Adventure: Working Women, Popular Culture, and Labor Politics at the Turn of the Twentieth Century (New York: Columbia University Press, 1999); Michael Denning, "Cheap Stories: Notes on Popular Fiction and Working-Class Culture in Nineteenth-Century America," Special American Issue, History Workshop 22 (Autumn 1986): 1-17;

40. Streeby, Radical Sensations, 74, 89, 129, 137, 165; Tomàs Almaguer, Racial Fault Lines: The Historical Origins of White Supremacy in California (Berkeley: University of California Press, 2009); Ken GonzalesDay, Lynching in the West: 1850-1935 (Durham, NC: Duke University Press, 2006); Ralph Chaplin, Wobbly: The Rough and Tumble Story of an American Radical (Chicago: University of Chicago Press, 1948), 277-80.

41. Bufe and Verter, Dreams of Freedom, 99; Juan Gómez Quiñones, Sembradores: Ricardo Flores Magón y el Partido Liberal Mexicano: A Eulogy and a Critique (Los Angeles: Chicano Studies Center, Aztlan Publications, UCLA, 1973), 68; Wood, "Death of a Political Prisoner," 38-66; Raat, Revoltosos, 287; Ethel Duffy Turner, Ricardo Flores Magón y el Partido Liberal Mexicano (Mexico: Comisiòn Nacional Editorial del C.E.N., 1984), 341.

42. Eugene V. Debs, "The Assassination of Magón," New York Call, December 3, 1922; "Salvajismo Inconcebible," C.R.O.M., May 1, 1923; Yale Sterling Memorial Library, Harry Weinberger Papers, Group No. 553 box 22, folder 24.

43. Gilbert O’Day, “Ricardo Flores Magón,” Nation, December 20, 1922, 689-90.

44. NA, BP, box 554, Inmate No. 13396; Bufe and Verter, Dreams of Freedom, 97; Raat, Revoltosos, 285.

45. Turner, Ricardo Flores Magón, 342-43; Gòmez-Quiñones, Sembradores, 68; Raat, Revoltosos, 288; Chaplin, Wobbly, 278-81; "Salvajismo Inconcebible" C.R.O.M.; NA, BP, box 554, Inmate Numbers: 13396. José Martínez's death is a subject of minor dispute among historians.

46. NA, BP, box 554, Inmate Nos. 13394-13401.

47. NA, BP, box 554, 13396.

48. "Andy" Lockhart, "At the Grave of a Felon," Leavenworth New Era (March 28, 1919), CHA, File 41738.

49. NA, BP, box 554, Inmate No. 13396; “Un Mexicano Preso Q' Muere De Sus Heridas,” El Heraldo De Mexico, December 1, 1922; Frank McLynn, Villa and Zapata: A Biography of the Mexican Revolution (London: Jonathan Cape, 2000), 323.

50. NA, BP, box 554, Inmate No. 13396; Cynthia Orozco, No Dogs or Mexicans Allowed: The Rise of the Mexican American Civil Rights Movement (Austin: University of Texas Press, 2009), 52-53.

51. On the struggle to build a "purposeful social movement," see Gilmore, Golden Gulag, 191-96.

52. Ricardo Flores Magón, "The Repercussions of a Lynching," Regeneración (November 12, 1910).

53. On the PLM and its struggle to organize transnational solidarities, see Streeby, Radical Sensations; Ricardo Flores Magón, “The Repercussions of a Lynching,” Regeneraciòn, November 12, 1910.

54. Flores Magón, "Repercussions of a Lynching."

55. Ricardo Flores Magón, letter to "Ellen White," November 12, 1922, Ricardo Flores Magón Collection, International Institute for Social History, Amsterdam.

56. NA, BP, box 554, 13396. 